\title{
The Problem of Euphemisms in the Medical Terminology of the English and Tatar Languages
}

\author{
Venera Khisamova ${ }^{1}$ \\ Liliia Abdullina ${ }^{2}$ \\ ${ }^{1}$ Professor, Doctor of Philological Sciences, \\ Institute of International Studies, Kazan Federal University, \\ Kremlyovskaya St, 18, Kazan, \\ Respublika Tatarstan, Russia, 420008 \\ ${ }^{2}$ Lecturer, Institute of International Studies, \\ Kazan Federal University, \\ Kremlyovskaya St, 18, Kazan, \\ Respublika Tatarstan, \\ Russia, 420008
}

DOI: https://doi.org/10.36941/jesr-2022-0oo3

\section{Abstract}

The article "The problem of euphemisms in the medical terminology of the English and Tatar languages" discusses issues related to euphemisms, in particular, the field organization of euphemisms in the medical terminology of the English and Tatar languages. The study uses a comparative analysis and the field organization of euphemisms in medical terminology is established to be the basis of comparison. Another method applied is the method of comparative interpretation and the principles of interpretation of the compared material of the two languages are determined. The results of this study make it possible to use the obtained theoretical outcomes and the collected lexical material in courses of general linguistics, lexicology and stylistics of the English and Tatar languages. In addition, the data obtained can be used in teaching professionally oriented English, for example in practical lessons of English language and while teaching translation practice to students of medical sciences. The lexical material obtained in the course of the research can supplement the existing dictionaries of euphemisms of medical terminology in the English language and form the basis of the dictionary of euphemisms of medical terminology in the Tatar language. Thus, one can observe the universal features of the field organization of euphemisms in English and Tatar languages for the first position of the first row, second, third and fifth rows. There are some differences in the rest of the ranks.

Key words: euphemism, field organization, medical terminology, English language, Tatar language

\section{Introduction}

Recently, the process of the formation of euphemisms has been proceeding with particular intensity. Euphemisms are a powerful means of forming new social attitudes and are extremely widespread in socially significant spheres of speech activity.

It is also important to note the fact that euphemisms do not just replace a specific linguistic unit 
- they interpret a certain phenomenon in a new way, consider it in a new perspective, offering a different moral and ethical assessment of it.

Euphemisms is a complex linguistic, social and cognitive phenomenon. It is reasonable to consider it not only in lexical and morphological terms, but also in a comparative aspect. Euphemisms are an accessible, appropriate form of replacing unwanted and inappropriate words in any given situation. These lexical units form the foundation of medical diplomacy. The use of euphemisms in medicine is dictated not only by psychological, but also by moral and social factors. A deliberately chosen language makes a significant contribution to achieving optimal results in diagnosis and treatment. In healthcare, euphemisms play a special role because they describe and represent facts that cause negative emotions. Moreover, medical euphemization is a new linguistic phenomenon that differs from traditional ethnocultural euphemization. It is also important to note the fact that euphemisms reflect the peculiarities of the national mentality, revealing the taboo phenomena in this culture.

Euphemia in the medical terminology of languages of different structures, which in this study are English and Tatar languages, has not been studied in a comparative aspect yet.

As a result of the study of the field organization of euphemisms in the medical terminology of genetically unrelated languages, one can find aspects which are common and different in relation to the field organization in the languages under consideration.

This article examines the field organization of euphemisms in the medical terminology of the English and Tatar languages. English is the international language of science, and Tatar is the second most widespread and as to the number of speakers of the national language in the Russian Federation.

\section{Theoretical Background}

Euphemism in medicine is defined by S.I. Madzhaeva as "intentional replacement of an existing word or expression with a more correct, softer one in order to avoid psychological trauma." She views euphemisms as a "defense mechanism." First, this psychological defense mechanism that ameliorates negative reactions with the help of words of broad semantics. Secondly, there is an associative mechanism that allows diverting attention from an unwanted subject. According to S.I. Madzhaeva, a characteristic feature of euphemisms in medical terminology is such an essential feature as the presence of an emotive component, which is motivated by a certain extralinguistic factor. She also believes the motivation allows considering the euphemism as a term. However, not all euphemisms are terms and even functioning within a certain terminology system, they can be located on its periphery, thereby taking their definite place in terminology [Madzhaeva, 2010, p. 57].

The formation of euphemisms is based on the overestimation of the name in comparison with the concept. The person who came up with the term euphemism, and then the people who use this term, enhance the positive effect, namely, create a discrepancy between the name and the concept, as a result of which the name becomes in an evaluative relation higher than the concept [Madzhaeva, 2010, p. 57-59].

Euphemia is characterized by ethical correctness, masking the essence of the matter. The spheres of its functioning are divided into personal (physiological processes, body parts, relations between the sexes, illness and death) and social (diplomacy, repressive actions of the authorities, state secrets, the military sphere, the service sector, ethnic, professional relations, etc.) [Sapiga et al., 2015, p. 76].

In medicine, there are several areas where euphemisms are commonly used. They, in most cases, are associated with extralinguistic factors: widespread asocial phenomena, infectious diseases, especially sexually transmitted diseases, diseases leading to death, etc. In the English language, a large number of euphemisms are used to denote asocial phenomena (about 16\%), the phenomenon of death (about 15\%). In the Tatar language, most euphemisms denote sick people, people with various pathologies and physical limitations (about 24\%), diseases (about 14\%) and asocial phenomena (about 11\%).

Among the terms that are considered to be euphemisms, lexemes with abstract semantics predominate, giving a neutral, indefinite idea of the denotation to the listener or reader. The breadth of semantics creates a veil that covers the negative essence of the phenomenon, thereby achieving the 
desired effect. At the same time, during semantic derivation, a contradiction arises "between their positive pragmatics in the context and negative semantics in the language system. As a result of the transfer of the euphemism outside the sociolect, the term loses its euphemistic effect, and it becomes the direct name of an unpleasant object or phenomenon. The effect of the utterance changes: instead of a positive one, it acquires a negative one. In medical terminology such principles of euphemisms as taboo, ethics, politeness and secrecy are observed" [Madzhaeva, 2010, p. 58-6o].

In medical terminology, there are such principles of euphemisms as taboo, ethics, politeness and conspiracy [Madzhaeva, 2010, p. 58-6o].

\section{Field Organization of Euphemisms}

When systematizing euphemisms, N.V. Tishina considers the concept of prototypical structuring, which assumes that each of the categories has a core and periphery, fluently passing into other categories. Psychologically, the most distinguished objects of reality form a core - a prototype, while objects that have at least one feature with a prototype belong to the periphery. At the same time, objects that have a large number of adjacent features with the prototype are located closer to it, and the least similar ones are farther from the center. According to N.V. Tishina, the study of the problem of euphemia in the light of the theory of the field organization of mental and linguistic categories and the hypothesis of prototypes is very promising, since the euphemistic substitution is based on a whole system of lexico-stylistic devices subordinated to a specific purpose of the statement. The field organization of euphemisms will reveal the relationship between different types of euphemisms. In order to achieve this, the author classifies euphemisms and defines them, highlighting the classification dominant and establishing a system of relationships between all classes based on the center-periphery principle.

N.V. Tishina defines a euphemism as a preference for vocabulary with neutral or positive connotations over vocabulary with negative connotations.

It is also important to note the fact that euphemisms differ semantically (words with positive, neutral or less negative connotations than the original concept), stylistically (euphemisms of scientific style, professional jargons, slang, colloquial literary language, codified literary language), in relation to the levels language (implication of euphemistic meaning at the level of a word, phrase or text) and by the way of formation. Accordingly, they can be divided into groups with more or less clear boundaries, highlighting the most characteristic euphemisms that make up the core of this field and substitutes that make up the periphery and less suitable for the central definition of a euphemism.

From a linguistic point of view, euphemisms have two levels: the level of form and the level of meaning. Euphemisms of the level of meaning aim to veil the content of a concept by creating a semantic link with the word being replaced. They have a strong ameliorative effect with simultaneous stability in the language; therefore, the level of meaning is more important than the level of form, based on the replacement of only the sound form. When creating a semantic connection, a word is selected from the vocabulary of the language already with an existing non-stigmatized meaning, and when it is perceived, the listener has associations that hint at the stigmatized concept and, at the same time, "distract" from this concept. Semantic euphemisms are divided into occasional and conventional.

Common or usual euphemisms are lexical units fixed in general or special dictionaries, or very often found in texts and oral speech with a given euphemistic meaning. At the same time, the euphemistic meaning does not require any explanation or parallel use of direct names in the text. The meaning of such euphemisms is revealed regardless of the context. Non-conventional ones include euphemisms of professional vocabulary and jargons, formed according to the principle of polysemy, that is, lexical units in which the euphemistic meaning is not the only one and is not the first. This group of euphemisms also includes occasional words, which are individual contextual substitutions, neologisms and part of lexical units with broad semantics. They are characterized by limited use and require clarification in context when used outside the scope of professional discourse.

A form-level euphemism is a phonetic-graphic euphemism. Its essence: 
1. In the choice of a word already available in the language, not by semantic, but by phonetic and less often by graphic similarity to create a euphemistic replacement, e.g., Eng. departed - dead, etc.;

2. In the use of borrowings with the same meaning from a foreign language or professional vocabulary of the native language, e.g., Eng. anorexic instead of thin, Tat. neoplasm instead of shesh, etc.;

3. In the creation of a new lexical unit, formed from the original, e.g., Eng. mis(s) instead of miscarriage, Tat. tbs instead of tuberculosis, etc.

While creating euphemisms of this kind, an important role is given to phonetic similarity. Sometimes a semantic relationship with the word being replaced can be found, but it is rather accidental. Such euphemisms are often formed through contamination and travesty techniques. They are not always called upon to carry out a euphemistic function, i.e. the euphemistic meaning is either not assigned to them in the language, or, if it is fixed, then such a euphemistic meaning turns out to be unstable and ineffective. This is the difference between the euphemism of form and the euphemism of meaning. They have a weak reclamation effect, since they do not offer a new positive interpretation of the stigmatized phenomenon, but only replace the taboo word in such a way that it allows the recipient of the information to establish direct associations with the stigmatized concept, therefore the euphemisms of the form refer to the peripheral row of euphemia. Phonetic-graphic euphemisms can be complete or partial. Complete phonetic-graphic euphemisms include euphemistic units, the implicit meaning of which is difficult to understand. It is difficult to divide euphemisms-forms into ordinary and occasional ones, since they are not as widespread as semantic euphemisms. Their usability is conditional, i.e. these are either substitutes borrowed from terminology and used as euphemisms in limited situations, or euphemisms that are part of the literary language, but are used quite rarely. Some euphemisms of form, such as foreign language and professional borrowings, are euphemisms only contextually, e.g., alopecia in a scientific context performs the function of only an exact term, but in colloquial speech, it can be used instead of the word bald, etc.

Both semantic and phonetic-graphic euphemisms can be: 1. Widely used in a codified and spoken literary language; 2. Occasional words acceptable in the literary language; 3. Updated lexical units of professional and social jargons; 4. Occasional words, found in professional and social jargons; 5. Usual lexical units and occasional words of reduced vocabulary. In each of these groups, euphemisms are isolated: 1. with positive or neutral connotation; 2. with less negative connotation than the original concept; 3 . there are no emotional coloring (this group includes phonetic-graphic euphemisms).

Thus, the main criterion for the classification of euphemisms is the intensity or degree of ameliorative effect. If euphemism has such properties as a focus on veiling or softening, strong meliorative effect, and it is usual and stable in the literary language, then it refers to the center of euphemia and if there is no at least one of these properties, it moves to the periphery.

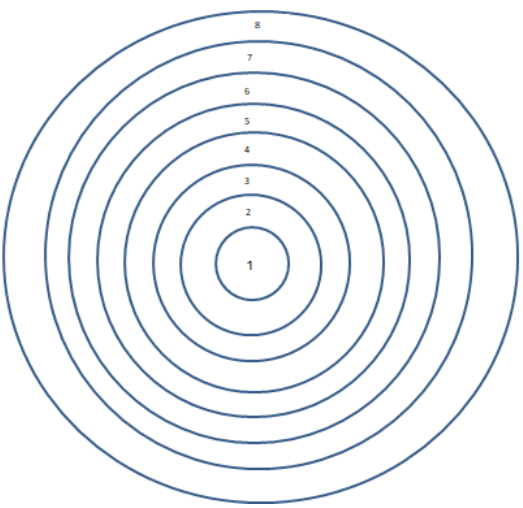

Figure 1: The picture represents the field organization of euphemisms 
The first row corresponds to the center of euphemisms, the second round is the second row, etc. Each row is conditionally divided into euphemisms of a codified and spoken literary language and euphemisms of colloquial language. Euphemisms, belonged to a codified literary and colloquial literary language, found in the texts of the media, fiction, texts created by the administrative bodies of the state, in everyday conversation peculiar to native speakers of literary language and recorded in dictionaries. The euphemisms of colloquial language forms include lexical units belonging to special jargons, but fairly acceptable and permissible among the native speakers of literary language, and vulgarisms that are not allowed among the native speakers of colloquial language.

The most characteristic type of euphemisms forms the center of this lexical category and separates it from other types of ameliorative lexical units. Such euphemisms-prototypes include a pragmatically conditioned means of language, consisting in the designation of a stigmatized concept and / or concept that cannot be called directly in some communication situations, and which is a common lexical unit with a positive and neutral connotation that does not completely coincide with the original concept from the semantic point of view. Euphemisms of the first row can include conventional substitutes based on stylistic devices such as paraphrases, antiphrasis, allegories, metaphors, metonymic transference, synecdoche related to codified or colloquial literary language. The semantic substitutes of the first row include, first of all, the lexical units of the literary language, and, secondly, the euphemisms of special jargons.

N.V. Tishina consideres the nature of the distribution of medical euphemisms from the center to the periphery, based on the theory of field organization of euphemia. According to the principle of field organization of euphemia, common euphemisms with a positive or neutral evaluative component belong to the first row of euphemisms. Such euphemisms are formed using lexical units of both literary and non-literary languages. At the same time, literary euphemisms have advantages over non-literary ones in terms of the possibility of their use by all groups of native speakers and in any situation, therefore they occupy the first position in each row.

\section{Field Organization of Euphemisms in English}

The first group includes the usual positive and neutral euphemisms of the first and second positions of the first row. Such euphemisms in English include the following: mature-old and fat, conceive become pregnant, hot flashes - menopause, aurally challenged - deaf, etc. Euphemisms of the first row are intensively replenishing the English language due to expressive figurative means of neutral, colloquial and book vocabulary, e.g., golden age - old age, muster your bag - be ill, off-color - ill, ticker heart, etc.

In English, there are more synonymous chains with euphemisms with a neutral or positive connotation than in the Tatar language, e.g., physically-challenged - differently abled - people with differing ability - uniquely abled.

The second position of the first row includes semantic euphemisms of slang. They occupy an important place in English language. Such units include, e.g., camisole - straitjacket, snip - to make a vasectomy, cocoa - mad, etc. At the same time, a euphemism can consist of units of a codified literary language, but itself refers to jargon, slang, argot. Such euphemisms can include both semantic euphemisms, e.g., overdue - pregnant, and euphemisms of the form, ex., raspberry - raspberry ripple cripple etc.

Euphemisms of the second row are defined as a pragmatically conditioned means of language, consisting in the designation of a stigmatized concept and / or concept that cannot be called directly in some communication situations, and is a non-conventional linguistic means with a neutral or positive connotation that semantically does not completely coincide with the original concept. Euphemisms of the second row include lexical substitutions, the use of which is determined by the individual characteristics of the linguistic personality and the choice of the author, but which have not become facts of the language.

Euphemisms of the second row are non-conventional euphemisms with a positive or neutral 
connotation - include occasional units, e.g., serious conditions - pathologies, sickness, strong family history - bad heredity, etc.

As euphemisms of the third row, a pragmatically conditioned language means is considered, which consists in designating a stigmatized concept and / or concept that cannot be called directly in some communication situations, and which is a polysemantic lexical unit or a word with broad semantics. This includes substitutes-hyperonyms and polysemantic units. Substitutes-hyperonyms are based on the process of expansion of meaning. The abstractness of the meaning makes the addressee a neutral or less negative impression of the denotation. The meaning of these units and their status as euphemisms are disclosed only in context

The third row includes such polysemantic words and expressions and words with broad semantics, e.g., case - patient's name, disorder - illness, turn - sudden illness, decline - the fatal onset of pulmonary tuberculosis, etc. This may include euphemisms with a positive or neutral connotation, and euphemisms of mitigation with a less negative connotation than the original name.

Euphemisms of the fourth row are a pragmatically conditioned means of language, consisting in the designation of a stigmatized concept and / or concept that cannot be called directly in some communication situations, and is a common lexical unit that differs from the original concept in a less negative connotation. A group of euphemisms with a less negative connotation than that of the original concept can be designated as softening euphemisms, since their pragmatic goal is not complete smoothing, but only softening of the negative emotions that this concept evokes. The euphemisms of the fourth row comprise designations using words and expressions with a less negative connotation than the original concept, including the method of litotes.

Usual phrases with a less negative connotation than that of the original name, that is, softening substitutions, make up the fourth row. The effect of reclamation in this case is lower, since the euphemism retains a negative connotation, although to a lesser extent. In English, euphemisms of this row are formed based on the material of the figurative use of book, general literary and literarycolloquial means, e.g., falling sickness - epilepsy, Dutch headache - hangover, Irish fever - typhus. In addition to these types, there are euphemisms with a non or no component in the English language, e.g., no chicken - old, non-compos poopoo - alcohol intoxicated, etc. There are synonyms-euphemisms with less negative connotation than the original unit in scientific English, e.g., social disease - veneral disease, passive overconsumption - overeating, with hearing impairments - deaf, etc. Due to the geographic prevalence of the English language and the presence of territorial variants, synonymous variants-euphemisms appear. English is represented by variants such as British, American, Australian ones. In addition, Scottish and Irish dialects of English are also distinguished in Great Britain. This variation is reflected in medical terminology, e.g., falling evil (Brit.) - falling sickness (Scott.), vomit throw up (common colloquial) - throw a map ( $A u E)$, throw one's voice (AuE, AmE), throw up your toenails (AuE, slang) - throw up one's accounts (BrE) - cast one's accounts (BrE).

The fifth row includes euphemisms that differ from the fourth row in that they are of an occasional nature, i.e. are not fixed in the language and their meaning requires disclosure by the context. It means that the fifth row is occupied by non-conventional euphemisms of softening, e.g., unsafe collection practices - infecting during blood collection, which can only be understood in context.

Further, the rows are united according to the principle of euphemization at the level of form. This principle consists in partial or complete change of the sound or graphic shell of a stigmatized concept.

The sixth row of euphemisms is defined as a pragmatically conditioned means of language, consisting in the designation of a stigmatized concept and / or concept that cannot be called directly in some communication situations, and is a complete synonym for the original lexical unit, which has a form completely different from the original word or expression, i.e. this group includes phonetic and graphic euphemisms. Among them there are foreign language and terminological borrowings in the form of words or phrases, uncommon abbreviations, including those borrowed from professional vocabulary, apocopes and their derivatives, methods of contamination and travesty, consisting in the 
selection of a euphemistic substitution according to the punning consonance of the substitute and the substituted word, often even with the effect of a playful semantic similarity.

The sixth row consists of euphemisms - scientific terms. In this case, borrowings play an important role, especially if they are from the ancient Greek and Latin languages, in addition from other terminological systems, as well as changes in the form of the original word or expression using contraction and ellipsis. Their goal is to replace or soften stigmatized concepts at the level of form on a par with non-terminological foreign language borrowings, e.g., anorexic - thin, lean, hemorrhage bleeding, stroke, etc. Instead of the expression test-tube baby, it has recently become customary to say IVF baby (in-vitro fertilization baby), hospital is replaced by clinic, e.g., mental health clinic instead of mental hospital. In English, when euphemizing with borrowings, French language plays an important role, e.g., the French word enceint instead of pregnant. Together with borrowings from foreign languages and terminological systems, phonetic-graphic euphemisms of the sixth row include such common abbreviations as $B O$ - body odour - stale sweat, big $C$ - cancer, big $D$ - death, common euphemisms of medical jargon, e.g., $D$ and $C$ - dilatation and curettage, occasional abbreviations, e.g., $C$, depending on the context, can be interpreted as cancer or cocaine, etc. This row also includes pseudo-terms formed according to the principle of scientific terms (foreign language borrowings, eponyms), which are more likely to refer to a non-literary language, as they are used in professional jargon and outside of codified colloquial vocabulary, e.g., terminal patient - death sick. Phonetic substitutions of this row include geed up, borrowed from the Scottish jee, meaning crooked.

The seventh row of euphemisms includes a pragmatically conditioned means of language, consisting in the designation of a stigmatized concept and / or concept that cannot be called directly in some communication situations, and which is a complete synonym for the original lexical unit, having a form that partially coincides with the original word or expression. These are phoneticgraphic euphemisms with a transparent form, which include ellipsis, partial abbreviations (apocopes, syncopes, apheresis, and epenthesis), widely used abbreviations, contamination of words that clearly resemble the direct name.

The seventh row is occupied by incomplete phonetic-graphic euphemisms of softening, which in their form contain a sign of a stigmatized lexical unit, e.g., crinkly - old (by phonetic similarity to wrinkly). This also includes euphemisms formed using ellipsis, e.g., miss can mean miss a period or miscarriage, etc.

In the eighth row, euphemisms are from the field of reduced vocabulary and vulgarisms. They are defined as a pragmatically conditioned means of language, consisting in the replacement of diminished vocabulary and vulgarisms, which is a lexeme slightly modified semantically or phonetically in such a way as to soften the negative emotions of the listeners, but implying this depreciated meaning and related to diminished vocabulary. Such euphemisms are used to insult, express rude, familiar or negative words about a person or thing. The pragmatic attitude in this case is the release of strong emotions. In this case, euphemisms are formed using a softened expression with a less negative connotation, as well as the replacement and rearrangement of letters, sometimes leading to a change in the word beyond recognition.

The main role in this case is played by irony, travesty, and demonstration of a certain status (for example, demonstration of belonging to a youth or some low social group), while the goal of euphemization plays a secondary role. This group includes the vulgarisms of the English language, e.g., cream crackered - exhausted, canned - drunk, etc. [Tishina, 2006, pp. 23-40, 94-107].

\section{Field Organization of Euphemisms in the Tatar Language}

In the Tatar language, the first position of the first row includes such euphemisms as salqın tiyü ORZ/acute respiratory disease, irudan qalu - klimaks/menopause, qoyaş balaları - Daun sindromı bulgan balalar/children with Down syndrome, ğadäti bulmağan, mömkinlekläre çiklängän ğarip/disabled, balağa uzu - avırğa uzu/to be pregnant, ölkän - qart/old, taz - qorçañgl/scabies, berençe sanlı tabib - terapevt/therapist, qara botaq - arpa/sty, dävahanä - bol'nitsa/hospital, etc. 
The second position of the first row in the Tatar language includes euphemisms with positive or neutral connotations from the colloquial vocabulary, e.g., borınnan ağıp toru - rinit/rhinitis, Ğali baba - sönnätçe/a person who does genital mutilation, etc. In contrast to the English language, there are euphemisms that have several synonyms in this group of the Tatar language, e.g., the word yülär/mentally ill man has the following synonyms: vintı ıçkınğan, bașniñ șörepläre bulmau, yözgä beräü tulmağan, tuqsan tuğızl, ber taqtası kim, etc. In addition, euphemisms of the form are not found in this group of the Tatar language.

In the Tatar language, euphemisms of the second row include such euphemisms as alip qaytu yoqtıru/infecting, ömetsezlek - depresiya/depression, qanatları qaerılğan - inalid/disabled, aq xalat kiyüçe, şäfqat' iyäse, aq färeştä - tabib/doctor, etc.

There are also euphemisms of the third row in the Tatar language, e.g., xäbär symptom/symptom, kopiya - sostavında matdälärneñ qayan alınğanı bilgesez bulğan darular/ drugs consisting of substances with unknown origin, imitatorlar - arzan daru nigezendäge darular/drugs based on cheap drugs, afät - alkogolizm/alcoholism, etc.

In the Tatar language, euphemisms of the fourth row make up the majority of euphemisms. The euphemisms formed with the help of the word tügel were included in this row, e.g., sau tügel invalid/disabled, yäş tügel - qart/old, etc. The group of common euphemisms with less negative connotations than the original concept in the Tatar language includes the following: mäxäbbät avıruları, äxlaq avıruları - venerik avırular/sexually transmitted diseases, eç sleqlanu - eç kitü/diarrhea, aqılğa beraz say - yülär/mentally ill, normadan taypılıș - patologiya/pathology, birän avıruı - şikär avırul/diabetes, üpkä çire - tuberkulyoz/tuberculosis, irlek organnarl - censi organnar/genital organs, pıçraq qullar avıruı can be used instead of the following terms eçäk infektsiyäse/intestinal infection, gepatit A/hepatitis A, parasit sualçannarnıñ organismğa kerüe/parasitic invasion, etc. In the Tatar language, as in English, there are dialect variants of terms that are considered as euphemisms, e.g., räncü - avıru, tudıru köçänkese - tulğak, etc.

In the Tatar language, the fifth row includes the following euphemisms ömetsez avıru, mäkerle avıru - rak/cancer, populyar avıru - cenes bize adenoması, zamana çire, zamana afäte, aq ülem, can həm tän avıruı - narkomaniya/drug addiction, avıruı totu - epilepsiya/epilepsy.

In the Tatar language, the terms that make up the sixth row can be borrowed from other languages through the Russian language. In general, borrowings from scientific terminology are used as euphemisms of the sixth row in the Tatar language, e.g., konstipatsiya - eç qatu/ constipation, işuriya - sidek totqarlanu/ischuria, etc. Euphemisms-abbreviations in the Tatar language are usually borrowed from the Russian language.

In the Tatar language, only one incomplete phonetic-graphic euphemism was found: tbs tuberculyoz/tuberculosis, therefore the seventh row of the Tatar language includes only euphemisms discovered with the help of ellipsis, ex., tartuçı - tämäke tartuçı/smoker, çömergän - araqı çömergän/drunk, salğan - araqı salaam/drunk etc.

In the Tatar language, euphemisms of the eighth row include ones: șeșä yalau - araqı eçü/drinking alcohol, ötek - zäğıyf/invalid, şır söyäk - yabyq/thin, Vodkinskiga kitü - iserü/getting drunk, etc. Euphemisms with the words cen/jinn, shaytan/evil jinn of Arab mythology can be included in this row in the Tatar language, since in Islamic theology the shaitan is a representative of the category of evil spirits hostile to Allah and people, and the jinn are considered servants of the Satan who can seriously harm people, therefore some medical concepts are replaced for by euphemisms based on these religious phenomena, ex., cen suqqan - paraliçll/paralyzed, cen qoru zäxmäte, cen kibü zäxmäte - yñäç ragl/esophagus cancer, shaytan sul - arakl/vodka, etc.

\section{Results}

The first position of the first row in the English and Tatar languages consists of euphemisms formed by the figurative means of neutral, colloquial and book vocabulary. In English, there are more synonymic chains of euphemisms, which have neutral or positive connotation. The second position of 
the first row in the English language includes semantic euphemisms of slang and euphemisms of form, in the Tatar language, this group includes euphemisms with positive or neutral connotations from colloquial lexicon, among which there are euphemisms with a large number of synonyms. Euphemism-forms have not been found in the Tatar language. Second row euphemisms in both English and Tatar are non-usual euphemisms with a positive or neutral connotation. The third row consists of euphemisms with positive or neutral connotations and euphemisms of softening with less negative connotations than the original name in both languages. The fourth row includes euphemisms representing usual constructions with a less negative connotation than that of the original name, e.g. softening substitutions in English and Tatar. Moreover, in English, territorial variants (American and Australian) and dialects are used as euphemisms, and in Tatar, dialect words; besides, words with the component no, non, in the Tatar language with the postposition tügel. In both languages, the fifth row is occupied by occasional euphemisms. Scientific terms and abbreviations act as euphemisms in the sixth row. This phenomenon can be applied to both English and Tatar languages. In English, in addition, there are phonetic and graphic euphemisms; borrowing from French is widespread, in Tatar, borrowings go through Russian. The seventh row includes incomplete phonetic-graphic euphemisms and euphemisms formed with the help of an ellipse. In the English language, phonetic-graphic euphemisms are often found, but in the Tatar language only one phonetic-graphic euphemism was found, but the use of euphemisms formed as a result of ellipsis is widespread. There are vulgarisms in the eighth row of euphemisms in the medical terminology of the English language; in the Tatar language, this group includes euphemisms based on religious phenomena.

\section{Conclusion}

Thus, one can observe the universal features of the field organization of euphemisms in English and Tatar languages for the first position of the first row, second, third and fifth rows. In the rest of the rows, there are some differences in the languages under consideration, which show the national characteristics of the euphemia. These differences are explained by various linguistic and extralinguistic factors such as different principles of speech etiquette in Tatarstan and Englishspeaking countries, different attitudes towards the health problem in Tatarstan and English-speaking countries, lexical and morphological features of the English language, the influence of religion on the coverage of certain issues regarding the human body, about which it is not accepted to speak openly.

\section{Acknowledgement}

This paper has been supported by the Kazan Federal University Strategic Academic Leadership Program.

\section{References}

Akcharlak. [Online] Available: https://akcharlak.com/. (February: 02. 2021).

Beznen. [Online] Available: https://beznen.ru/. (February: 05. 2021).

Doctors' slang, medical slang and medical acronyms and veterinary acronyms \& vet slang. In: Messybeast Portal.

[Online] Available: http://messybeast.com/dragonqueen/medical-acronyms.htm. (February, 10.2021).

Gilyazova, I.R. 2012. Protsess evfemizatsii v sovremennykh tatarskikh SMI. (The Process of Euphemization in Modern Tatar Media). In: Kazanskaya Nauka. n. 3, pp. 192-194.

Intertat. [Online] Available: https://intertat.tatar/. (February: 07. 2021).

Jamet, D. 2018. The Neological Functions of Disease Euphemisms in English and French: Verbal Hygiene or Speech Pathology? In: Lexis. n. 12. Online] Available: https://doi.org/10.400o/lexis.2397 (February, 01.2021).

Khanbikova, Sh.S. \& Safiullina, F.S. 2014. Tatar teleneñ sinonimnar süzlege. (Dictionary of Synonyms of the Tatar Language). Kazan: Tatar kitap näșriyätı. 
Madzhaeva, S.I. 2010. Evfemizatsiya kak sposob popolneniya meditisinskoi terminologii. (Euphemization as a Way to Replenish Medical Terminology). In: Gumanitarnyi Issledovaniya. n. 3 (35), pp. 55-61.

Rajić, T. 2014.Euphemisms in Medical Jargon: undergraduate's thesis: Osijek.

Shähri Kazan. [Online] Available: shahrikazan.ru. (February: 10. 2021).

Shi, Y. \& Sheng, J. 2011. The Role of Metonymy in the Formation of the Euphemism in Chinese and English. In: Journal of Language Teaching and Research. vol. 2, n. 5, pp. 1175-1179.

Sitdikova, F.B. 2007. Sposoby peredachi implitsitnoi informatsii v tatarskom literaturnom yazyke. (Methods of Transmission of Implicit Information in the Tatar Literary Language): Candidate's Thesis: 10.02.02. Kazan.

Söembikä [Online] Available: http://syuyumbike.ru/. (February: 14.2021).

Tatar Today. [Online] Available: https://tatar-today.ru/. (February: 06. 2021).

Tishina, N.V. 2006. Natsional'no-kul'turnye osobennosti evfemii v sovremennom angliiskom i russkom yazykakh. (National and Cultural Features of Euphemia in Modern English and Russian Languages): Candidate's Thesis: 10.02.20. Moscow. 